\title{
A Preliminary Study on Flight Characteristics of the Longhorn Date Palm Stem Borer Jebusaea hammerschmidtii (Reiche 1878) (Coleoptera: Cerambycidae) Using a Computerized Flight Mill
}

\author{
Hamadttu El-Shafie ${ }^{1,2} \mathbb{1}$, Maged Mohammed ${ }^{1,3, *} \mathbb{C}$ and Nashi Alqahtani ${ }^{1,4}$ \\ 1 Date Palm Research Center of Excellence, King Faisal University, Hofuf 31982, Saudi Arabia; \\ helshafie@kfu.edu.sa (H.E.-S.); nalqahtani@kfu.edu.sa (N.A.) \\ 2 Department of Crop Protection, Faculty of Agriculture, University of Khartoum, Shambat 13314, Sudan \\ 3 Agricultural and Biosystems Engineering Department, Faculty of Agriculture, Menoufia University, \\ Shebin El Koum 32514, Egypt \\ 4 Department of Food and Nutrition Sciences, College of Agricultural and Food Sciences, \\ King Faisal University, Hofuf 31982, Saudi Arabia \\ * Correspondence: memohammed@kfu.edu.sa
}

check for updates

Citation: El-Shafie, H.; Mohammed, M.; Alqahtani, N. A Preliminary Study on Flight Characteristics of the Longhorn Date Palm Stem Borer Jebusaea hammerschmidtii (Reiche 1878) (Coleoptera: Cerambycidae) Using a Computerized Flight Mill. Agriculture 2022, 12, 120. https://doi.org/ 10.3390 /agriculture 12010120

Academic Editor: Bin Gao

Received: 9 December 2021

Accepted: 14 January 2022

Published: 17 January 2022

Publisher's Note: MDPI stays neutral with regard to jurisdictional claims in published maps and institutional affiliations.

Copyright: (c) 2022 by the authors. Licensee MDPI, Basel, Switzerland. This article is an open access article distributed under the terms and conditions of the Creative Commons Attribution (CC BY) license (https:// creativecommons.org/licenses/by/ $4.0 /)$.

\begin{abstract}
The longhorn date palm stem borer, Jebusaea hammerschmidtii (Reiche), is a highly destructive beetle of edible date palm Phoenix dactylifera L. The flight capabilities and dispersal potential of this beetle are unknown, which hinders the planning for its proper management in date palm groves. In this study, the flight propensity of this insect pest was investigated using a computerized flight-testing system. The flight system consisted of a flight mill, a digitally controlled testing chamber, and a data logging and processing unit with a USB digital oscilloscope connected with a laptop. A total of 40 field-collected beetles of unknown sex and mating history were used in the experiments; about $34 \%$ of this number failed to fly on the flight mill. The relationship between temperature treatments $\left({ }^{\circ} \mathrm{C}\right)$ and flight speed $(\mathrm{m} / \mathrm{min})$, cumulative flight time $(\mathrm{min})$, and cumulative flight distance $(\mathrm{km})$ of the test beetles were studied using regression equations with correlation coefficients $\left(R^{2}\right)$ of 0.91 , 0.98 , and 0.98 , respectively. The maximum cumulative distance flown by the beetle was $11.5 \mathrm{~km}$ at a temperature of $35^{\circ} \mathrm{C}$, and a minimum distance of $2.4 \mathrm{~km}$ was recorded at $45^{\circ} \mathrm{C}$. The flight threshold of the beetle was $20^{\circ} \mathrm{C}$, at which flight activities ceased utterly. The velocity of the beetle increased with increasing temperature and reached a maximum of $107 \mathrm{~m} / \mathrm{min}$ at $40^{\circ} \mathrm{C}$, before starting to decline. The obtained information on the flight characteristics of the J. hammerschmidtii may aid in understanding the dispersal of this pest in date palm plantations and in setting up management strategies.
\end{abstract}

Keywords: longhorn; date palm; flight mill; dispersal; control; graphical user interface; regression model

\section{Introduction}

The edible date palm Phoenix dactylifera L. is widely cultivated under arid conditions and has many economical, aesthetical, and ecological values [1]. Globally, date palm suffers from many stresses that seriously weaken growth and reduce yield quantitatively and qualitatively. In addition, numerous insect pests inflict serious damage on date palms. However, only a few species cause economic damage that necessitates adopting management measures [2]. The longhorn date palm borer (LHB) Jebusaea hammerschmidtii (Coleoptera: Cerambycidae) (Reiche 1878) is a major pest of date palm grown in the Middle East and North Africa that causes serious damage [3-8]. This beetle belongs to the family Cerambycidae in the order Coleoptera, which has a relatively large body of $\sim 30-45 \mathrm{~mm}$ long and is characterized by having a very long antennae that may exceed the length of the body in the males [7]. The mitochondrial of the LHB has been announced recently; it includes 15,619 bp and contains 13 protein-coding, 22 transfer RNAs, and two ribosomal RNAs genes. Phylogenetically, the LHB belongs to the subfamily Cerambycinae with gene content 
and organization similar to other Cerambycid beetles [9]. The LHB is geographically found in Bahrain, Kuwait, Qatar, Libya, United Arab Emirates, Yemen Arab Republic, Iraq, Saudi Arabia, Algeria, Oman, Iran, and India [10]. The LHB is a true pest on date palm, so far, with no other known hosts [11-13]. The larva is the destructive stage that makes tunnels into the trunk of the date palm and can eventually lead to its death [14]. The LHB has only one generation per year (univoltine), and the adult beetles appear in the field in late April and early May for a very short time (15-20 days) [7].

Infestation by the J. hammerschmidtii begins when the gravid females lay their eggs at the base of palm petiole, on the cracks on the trunks, and on the young offshoots. Immediately after hatching, the developing larvae excavate undulating, intermingled, and irregular feeding galleries in the palm trunk [4]. The overall impact of LHB infestation results in shortening the date palm life span and reducing palm yield [15]. In addition, the tunnels made in the palm stem by the larvae reduce the aesthetic and quality value of the palm wood. The number of emergence holes and the presence or absence of live beetles affects the monetary value of the date palm orchards in Iraq [16]. Young offshoots (small side shoots or pups) are highly susceptible to infestation by the LHB [4]. The infestation of the offshoots tremendously limits the commercialization of such planting materials, which eventually reduces farmers' revenues. Like other cerambycid beetles, the LHB can be easily introduced into new uninfested areas through commercialization and transportation of infested palms intended either for plantations or landscaping purposes $[17,18]$. In addition to human-assisted dispersal, the LHB can disperse naturally in and between date palm plantations. Therefore, understanding the flight capabilities of $J$. hammerschmidtii is essential for designing management strategies. Flight mill is a valuable tool that has been used for a long time to quantify distance flown by insects $[19,20]$. Recently, computerized flight mills have been developed and used extensively by entomologists to study insects' flight behavior under laboratory conditions $[19,21]$. Although flying insects tethered to a flight mill arm and under a controlled environment differ significantly from flight under natural conditions, this practice provides clues and insights into the potential flight capabilities of the test insect [19]. Unfortunately, to our knowledge, no documented studies have been made on the flight capabilities of this beetle. The present investigation aims to study flight characteristics of J. hammerschmidtii, such as flight velocity and distance flown using a computerized flight mill under a controlled temperature.

\section{Materials and Methods}

\subsection{Adult Beetles}

Being a univoltine (one generation per year) with short-lived adults coupled with a relatively long larval stage $(\sim 1$ year) makes $J$. hammerschmidtii challenging to rear in the laboratory for obtaining a sufficient number of adults for the trials. Therefore, adults were collected in June 2021 from the field of the Date Palm Research Center of Excellence, King Faisal University at Al-Ahsa, Kingdom of Saudi Arabia (Latitude: $25.268528^{\circ} \mathrm{N}$, Longitude: $\left.49.707218^{\circ} \mathrm{E}\right)$ using an automated solar-powered light trap [22]. The traps were fitted with ultraviolet (UV-A) black light fluorescent tubes (BLF) with 350-400 nm wavelength (Mohammed et al., 2018). The captured beetles were brought to the laboratory in large plastic boxes provided with fresh-cut bases of date palm leaves to keep the boxes humid. The collection of the beetles from the traps was carried out in the early morning hours before sunrise, to avoid the beetles being killed by the hot temperatures. The adult beetles of $J$. hammerschmidtii are very sensitive to high ambient temperature. They cannot withstand temperatures above $45^{\circ} \mathrm{C}$ and, accordingly, they are usually found dead in the light traps if the collection is delayed until after sunrise [8]. The mating history and age of the field-collected beetles used in the trials were unknown. To our knowledge, no information or observation is available on the feeding biology or source of adult feed for this beetle, or whether they feed in the adult stage or not. Thus, the satiation status of the flown beetles can not be specified. 


\subsection{Computerized Flight Mill}

The computerized flight mill used in this study was designed by the second author [21] (Figure 1). Some modifications were made to the system to promote the fight of LHB under a controlled atmosphere condition. In addition, some preliminary experiments were carried out to verify the system's performance concerning mill operating accuracy and controlling in the microclimate of its testing chamber. Figure 2 shows the main components of the computerized flight-testing used to study the flight parameters of the LHB.

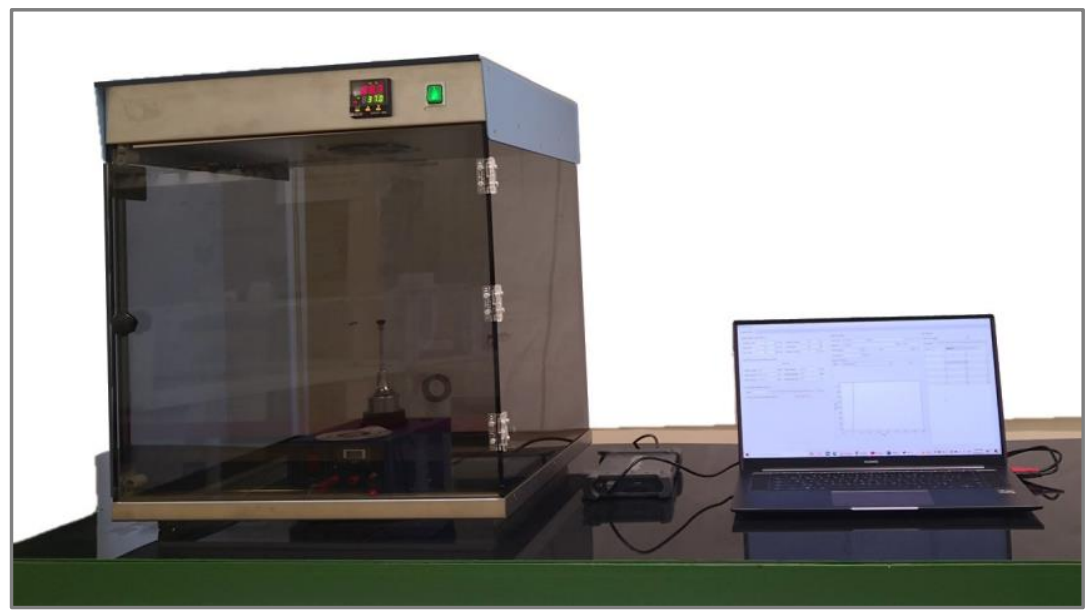

Figure 1. Image of the computerized flight system used to study the flight propensity of J. hammerschmidtii [21].

The first part of the system was the flight mill which had an arm that could be rotated and whose function was counting the rotation number when the LHB was tethered to its flight arm, and allowed to fly freely. The flight mill consisted of a box with $20 \mathrm{~cm}$ length, $10 \mathrm{~cm}$ width, and $10 \mathrm{~cm}$ height, with a thickness of $0.05 \mathrm{~cm}$ made from the galvanized sheet, a rotating part, and a digital counter. The rotating part consisted of an opaque plastic disc with ten equidistant holes on its periphery mounted on the spindle shaft lightweight. The spindle shaft diameter was $0.04 \mathrm{~cm}$, and made from aluminum to decrease the rotating friction. The rotating arm was made from highly flexible spring steel with $30 \mathrm{~cm}$ total length, $0.05 \mathrm{~cm}$ thickness, and $0.4 \mathrm{~cm}$ width to allow vertical free motion of the tested LHD. The rotating arm was attached to the spindle shaft, and LHB rotated it on the spindle rotation axis. When the LHD was suspended in this arm and left to fly freely, the arm and the rotor were rotated, and the holes of the opaque disk interrupting the IR (infrared light) of the attached optoelectronic switched to generate the signal. The output signals of the optoelectronic switch were wired with the comparator circuit to switch the output voltage from a low to a high state. Then the output signal of the comparator circuit was connected with the flight mill counter circuit. The second part was a testing chamber provided by digital controllers to control its inner temperature and relative humidity by a $300 \mathrm{~W}$ electric air heater with an automatic temperature controller and an ultrasonic humidifier with an automatic relative humidity controller. This testing chamber was made from 6-mm-thick PVC (polyvinyl chloride transparent sheets) with a length of $50 \mathrm{~cm}$, a width of $50 \mathrm{~cm}$, and a height of $62 \mathrm{~cm}$. The third part was the processing and data logging unit, which consisted of a digital oscilloscope connected with a laptop via USB (model: Hantek6022BE, Hantek Electronic Co., Ltd., Qingdao, China). The graphical user interface of the Hantek digital oscilloscope was installed on the laptop for real-time data logging and processing for flight time, and output signal count. The graphical user interface (GUI) designed and achieved by Mohammed et al. [21] was used to immediately find the actual flight time, rotation speed, flight speed, flight distance, mean flight speed, and cumulative distance. This GUI was installed on the laptop for real-time data processing of the LHB flight parameters (Figure 3). These flight parameters were determined based on the input data of actual flight time, 
target duration, rotation radius, and rest time based on the number of the signal recorded directly by the data of the USB digital oscilloscope, or by the counter of the flight mill. When the required data was entered, the results of the flight parameters were shown in a required form for total time, flight speed, and cumulative distance of the LHB flight based on the selected parameter by the slider. It was also possible to upload or import an excel file containing the flight data.

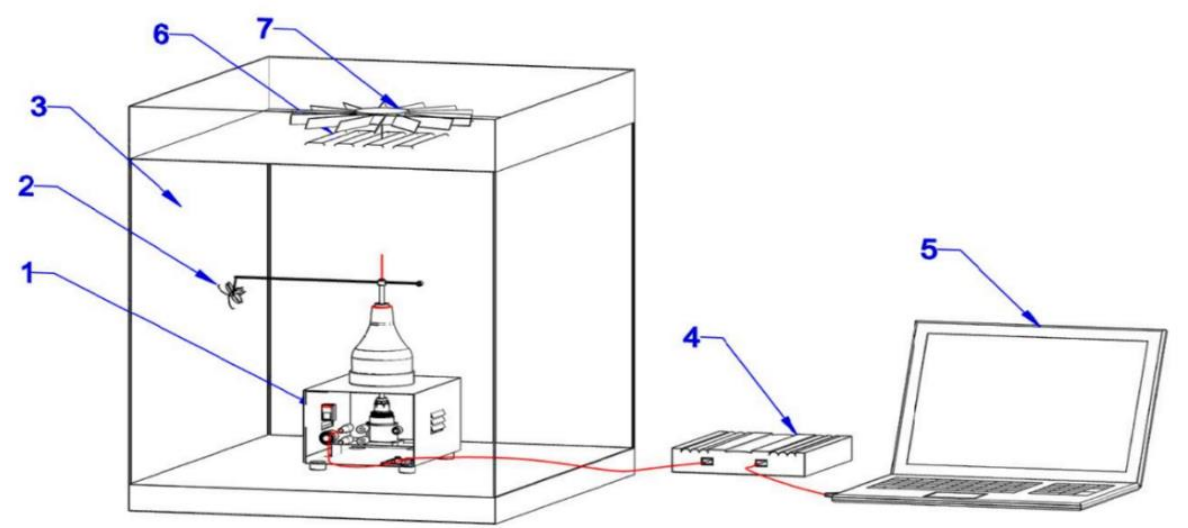

Figure 2. The main components of the computerized flight-testing system used to study the flight propensity of J. hammerschmidtii: (1) flight mill; (2) tested insect; (3) testing chamber; (4) USB digital oscilloscope; (5) laptop; (6) heater; (7) fane [21].

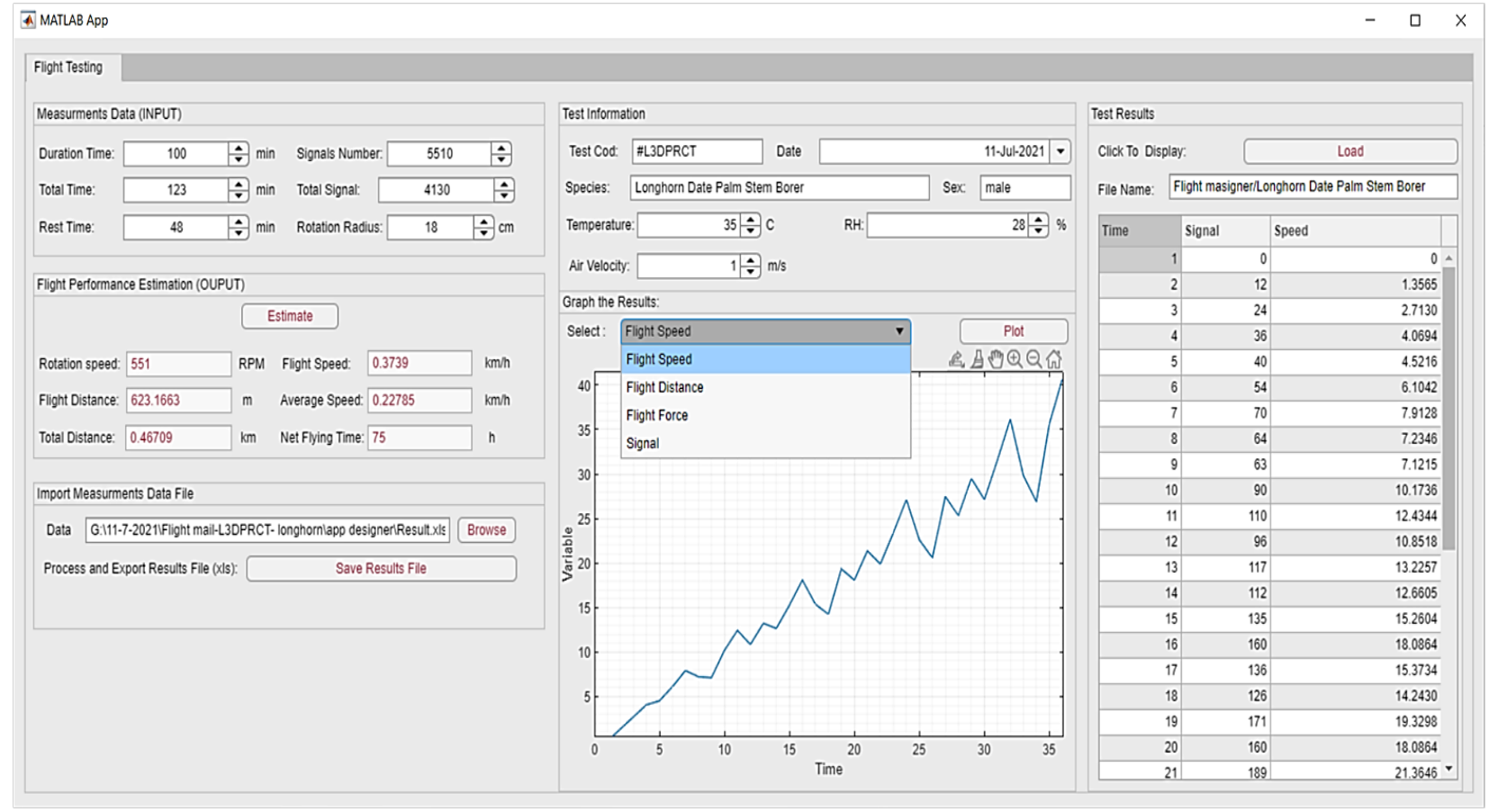

Figure 3. The graphical user interface (GUI) window for estimating J. hammerschmidtii flight parameters [21].

\subsection{Experimental Setup}

A total of 40 adult unsexed beetles of unknown age and mating status were flown on the flight mill to obtain flight metrics such as distance flown, flight velocity, and frequency and length of flight bouts. The morphometric characteristics of each beetle, such as mass, body length, width, thickness, calculated volume, density, and wing area, were measured before tethering on the flight mill. These measurements were used to calibrate the flight mill based on the flight coefficient, flight force, the moment of inertia, and the optimum 
suspension angle according to the described method by Mohammed et al. [21]. Then, the experimental beetles were tethered on the flight mill by their thoraxes, and they were attached dorsally to an " $\mathrm{L}$ "-shaped metal plate flattened at one end to facilitate insect adhesion. A small drop of Gorilla Super Glue Brush \& Nozzle was applied on the dorsal side of the beetle thorax. The flattened end of the metal plate was then immersed into the glue for $45 \mathrm{~s}$ to dry. The beetle was then fixed to the rotating arm of the flight mill by the distal part of the metal plate [19]. Before the experiment, the tethered beetles were carefully examined to make them move their wings and legs freely. Then, each test beetle was allowed to fly on the mill until it died.

To elucidate the effect of temperature on LHB flight characteristics, six different treatment temperatures of $20,25,30,35,40$, and $45^{\circ} \mathrm{C}$ were applied. Three replicates of each temperature were used under a controlled relative humidity of $35 \%$. Therefore, $18 \mathrm{LHB}$ were used through 18 workdays, since only one insect was tested daily. This number was chosen from 41 insects, as some insects did not fly after being suspended.

\subsection{Statistical Analysis}

The statistical analysis was conducted using one-way analysis of variance (ANOVA) by the statistical software package IBM SPSS (SPSS Inc., Version 24, Chicago, IL, USA). In addition, Tukey's multiple range tests were used to find means significantly different between the different treatment temperatures of $20,25,30,35,40$, and $45^{\circ} \mathrm{C}$ with three replicates at $p<0.05$. The regression models and the correlation coefficients were determined using Microsoft Excel (Microsoft 365).

\section{Results}

\subsection{Morphometric Parameters of the Test Beetles}

The mass, body size, volume, and density of 40 LHB are presented in Table 1 . These data are essential, and upon which the angle of tethering the beetle was based for the flight mill arm, as well as the beetle counterbalance weight on the opposite end of the arm. Additionally, based on the measurements of the morphometric characteristics, the flight coefficient of 1.13 and the suspension angle of $40^{\circ}$ for the tested LHB were applied to compensate for friction force between the rotating parts and reduce the circular flight motion resistance effects.

Table 1. Mean, standard deviation (Std), minimum, and maximum values $(n=40)$ of some morphometric characteristics of the tested J. hammerschmidtii.

\begin{tabular}{|c|c|c|c|c|c|c|c|c|}
\hline & \multicolumn{8}{|c|}{ Morphometric Characteristic } \\
\hline & $\begin{array}{l}\text { Mass } \\
\text { (g) }\end{array}$ & $\begin{array}{l}\text { Body Length } \\
(\mathrm{mm})\end{array}$ & $\begin{array}{l}\text { Body Width } \\
\text { (mm) }\end{array}$ & $\begin{array}{l}\text { Body Thickness } \\
(\mathrm{mm})\end{array}$ & $\begin{array}{c}\text { Calculated } \\
\text { Volume }\left(\mathrm{mm}^{3}\right)\end{array}$ & $\begin{array}{l}\text { Density } \\
\left(\mathrm{g} / \mathrm{cm}^{3}\right)\end{array}$ & $\begin{array}{l}\text { Wing Length } \\
(\mathrm{mm})\end{array}$ & $\begin{array}{l}\text { Wings Area } \\
\left(\mathrm{mm}^{2}\right)\end{array}$ \\
\hline Mean & 0.65 & 31.29 & 8.71 & 5.80 & 831.4 & 0.79 & 22.45 & 230.3 \\
\hline Std & 0.08 & 1.82 & 0.29 & 0.37 & 117.3 & 0.07 & 0.64 & 6.5 \\
\hline $\operatorname{Max}$ & 0.76 & 34.50 & 9.10 & 6.30 & 980.3 & 0.93 & 23.20 & 240.1 \\
\hline Min & 0.53 & 29.20 & 8.20 & 5.10 & 646.9 & 0.72 & 21.35 & 220.1 \\
\hline
\end{tabular}

\subsection{Effect of Temperature on Flight Characteristics}

Figure 4 shows the effect of atmosphere temperature on the ability of the insect to rotate the flight arm of the flight mill. There was a significant difference between the mean revolution per minute of the flight arm at the tested temperatures (ANOVA, $\mathrm{F}_{5,17}=182.9$, $p<0.001$ ). The flight arm's revolution was much higher at 35 to $45^{\circ} \mathrm{C}$ than $25^{\circ} \mathrm{C}$. The flight arm never moved at $20^{\circ} \mathrm{C}$, and no significant difference was observed between the mean value of the flight arm revolution (RPM) at the tested temperatures of $30,35,40$, and $45^{\circ} \mathrm{C}$. In comparison, there was a significant difference between these means and the mean value at $25{ }^{\circ} \mathrm{C}$ using Tukey's test. As shown in the trend line in Figure 1, the following regression 
model was obtained for the effect of atmosphere temperature on the arm revolution per minute with a correlation coefficient $\left(R^{2}\right)$ of 0.905 .

$$
\operatorname{Re}=-0.1 \mathrm{x}^{2}+7.77 \mathrm{x}-58.31
$$

where Re is the flight arm revolution (RPM) and $\mathrm{x}$ is the atmosphere temperature ${ }^{\circ} \mathrm{C}$.

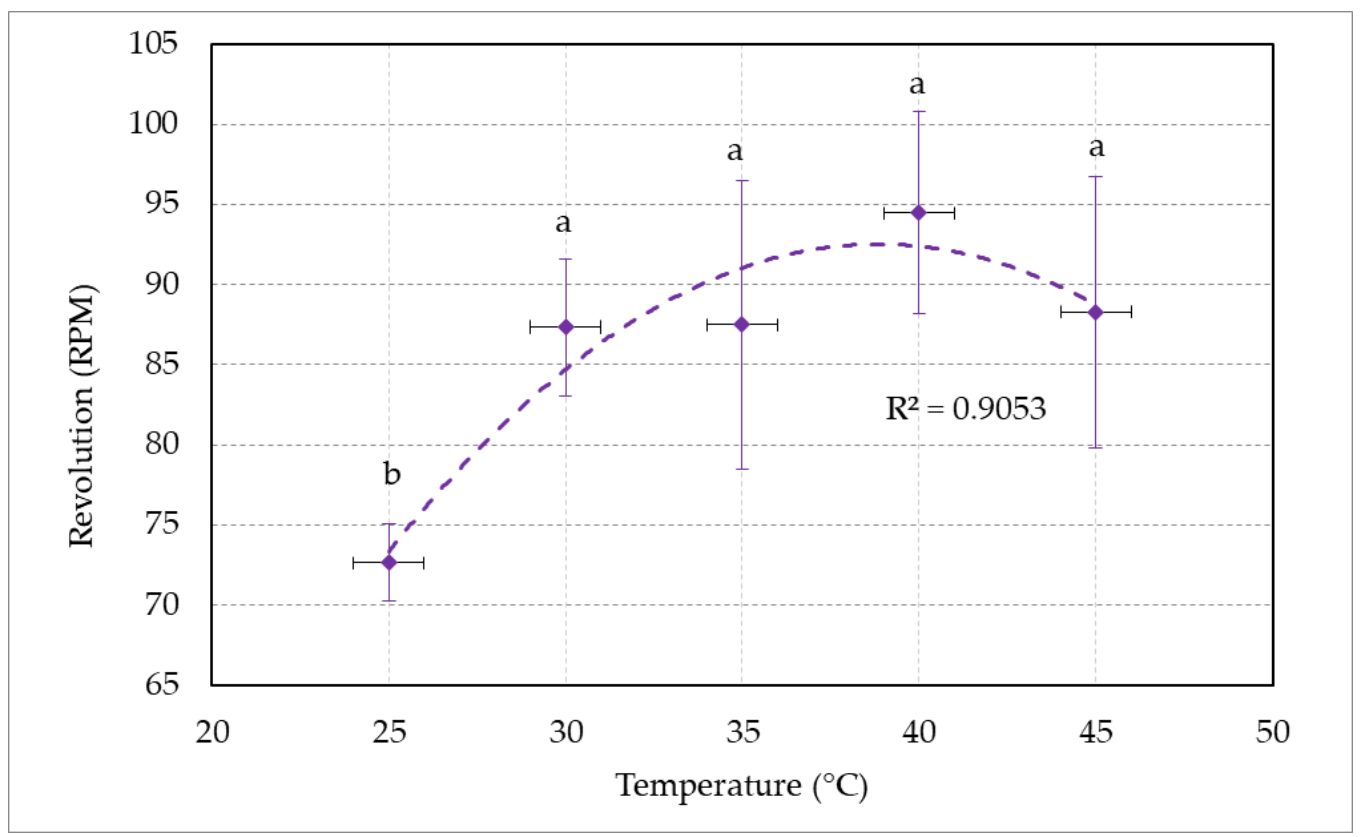

Figure 4. Effect of atmosphere temperature treatments on the J. hammerschmidtii ability to rotate the flight arm of the computerized flight mill at $\mathrm{RH}$ of $35 \%$. The different superscript letters show a significant difference between the means values $(p<0.05)$.

Figures 5-7 display the effect of atmospheric temperature on the flight speed $(\mathrm{m} / \mathrm{min})$, cumulative flight time ( $\mathrm{min})$, and cumulative flight distance $(\mathrm{km})$ of the LHB using the computerized flight mill system. There was significant difference between the mean flight speed (RM ANOVA, $\mathrm{F}_{5,17}=182.6, p<0.001$ ), cumulative flight time (RM ANOVA, $\mathrm{F}_{5,17}=50.92, p<0.001$ ), and the cumulative flight distance (RM ANOVA, $\mathrm{F}_{5,17}=36.31$, $p<0.001$ ) of the LHB under temperature treatments of $20,25,30,35,40,45^{\circ} \mathrm{C}$. The LHB stopped flying at $20^{\circ} \mathrm{C}$, and a normal flight was noted from 25 to $40{ }^{\circ} \mathrm{C}$. Based on these results, the temperature of $35^{\circ} \mathrm{C}$ is considered optimal for flying the LHB with a high cumulative flight distance of $11.20 \pm 2.4 \mathrm{~km}$. However, the maximum flight speed of $107.05 \pm 7.1 \mathrm{~m} / \mathrm{min}$ was achieved at $40{ }^{\circ} \mathrm{C}$.

The following regression equations express the relationship between temperature treatments $\left({ }^{\circ} \mathrm{C}\right)$ and flight speed $(\mathrm{m} / \mathrm{min})$, cumulative flight time $(\mathrm{min})$, and cumulative flight distance $(\mathrm{km})$ of the tested LHB with a correlation coefficient $\left(\mathrm{R}^{2}\right)$ of $0.905,0.981$, and 0.98 , respectively.

$$
\begin{gathered}
S=-0.11 x^{2}+8.78 x-65.91 \\
T=-0.44 x^{2}+28.81 x-390.04 \\
D=-0.066 x^{2}+4.44 x-63.73
\end{gathered}
$$

where $\mathrm{S}$ is the LHB flight speed $(\mathrm{m} / \mathrm{min}), \mathrm{x}$ is the atmosphere temperature ${ }^{\circ} \mathrm{C}, \mathrm{T}$ is the cumulative flight time ( $\mathrm{min})$, and $\mathrm{D}$ is the cumulative flight distance $(\mathrm{km})$. 


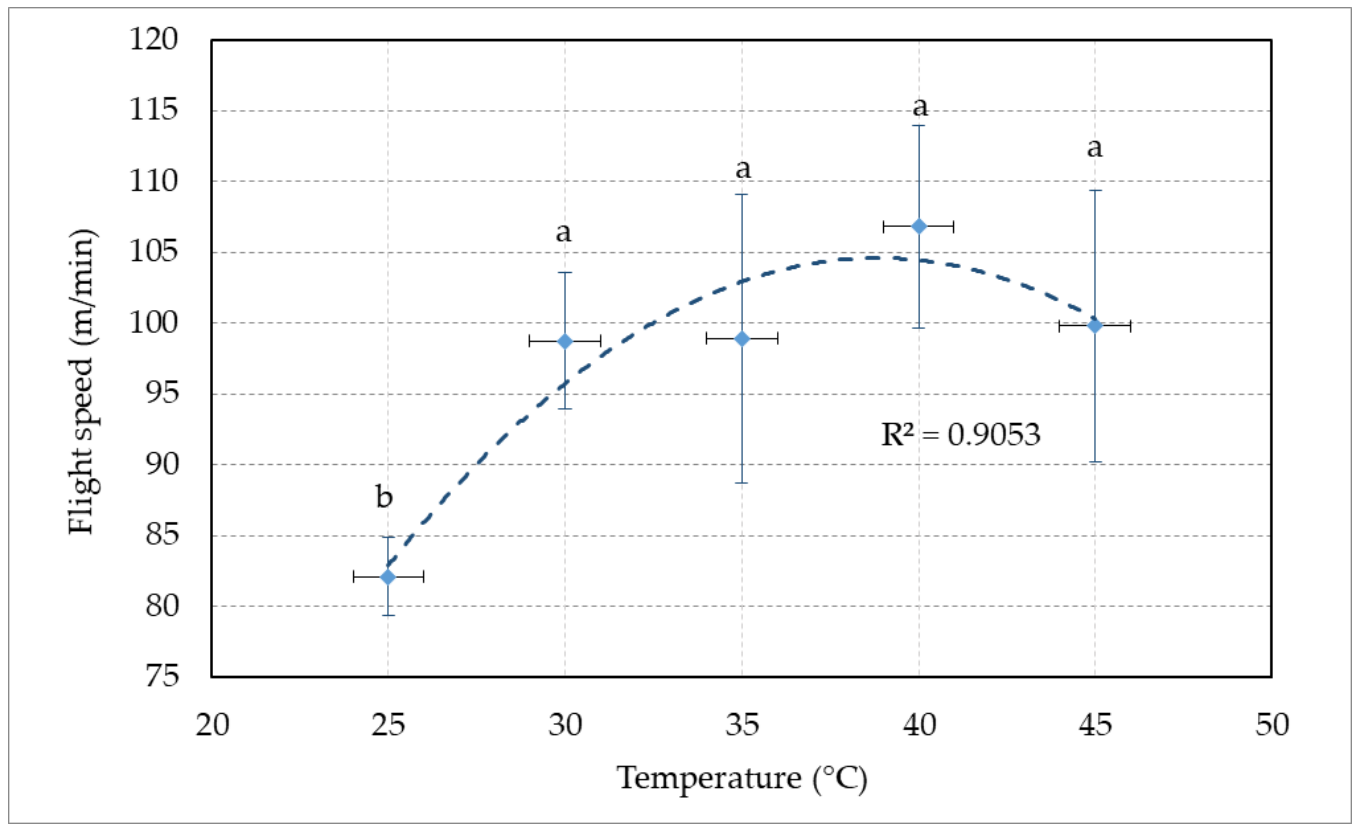

Figure 5. Effect of atmosphere temperature treatments on J. hammerschmidtii flight speed using the computerized flight mill at RH of 35\%. The different superscript letters show a significant difference between the means values $(p<0.05)$.

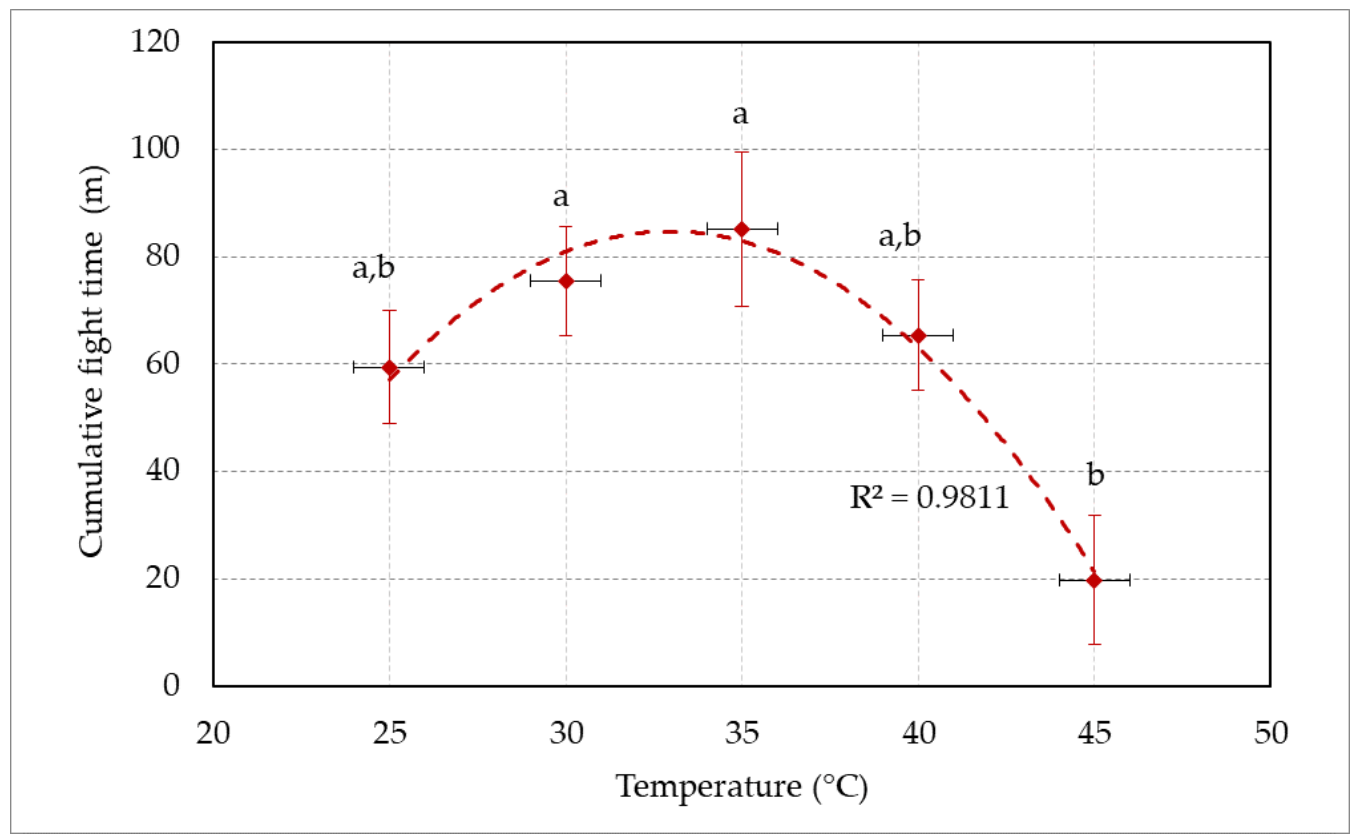

Figure 6. Effect of atmosphere temperature treatments on the cumulative flight time of the J. hammerschmidtii using the computerized flight mill at RH of 35\%. The different superscript letters show a significant difference between the means values $(p<0.05)$. 


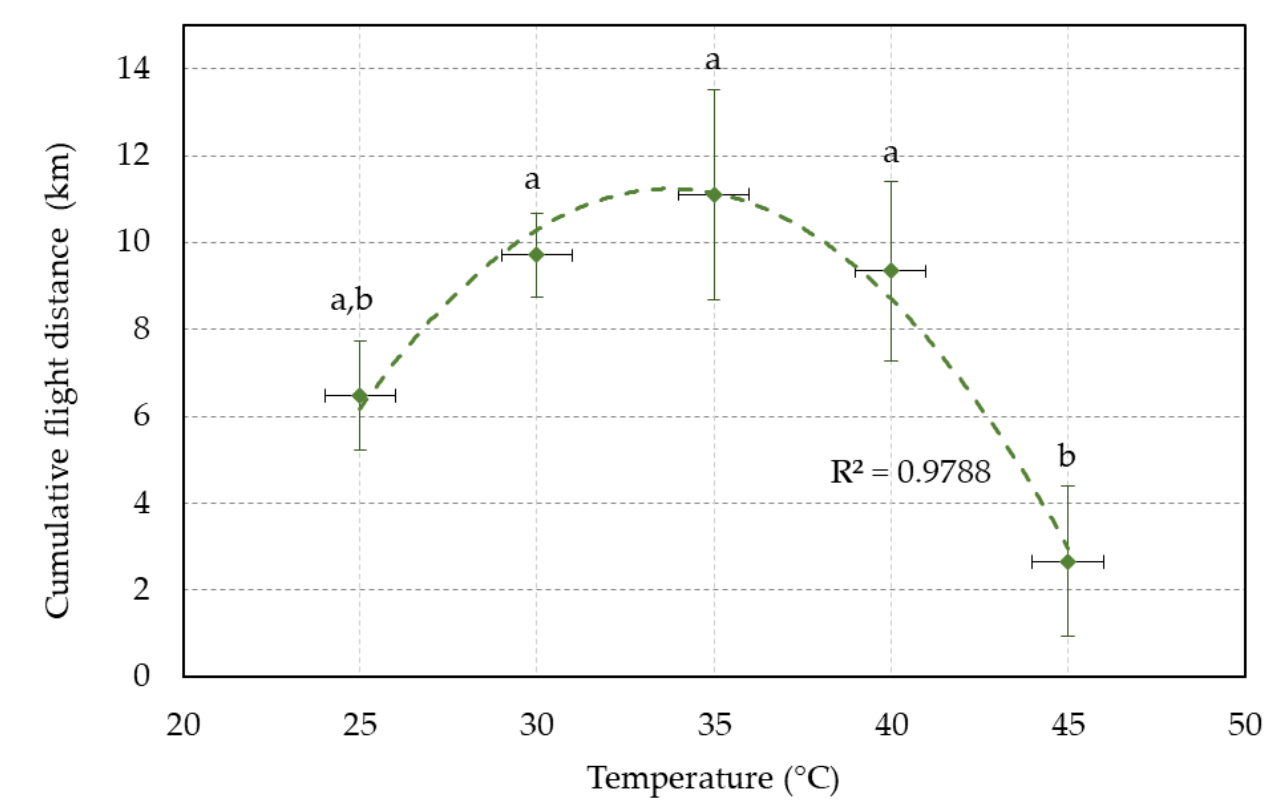

Figure 7. Effect of atmosphere temperature treatments on the cumulative flight distance of J. hammerschmidtii using the computerized flight mill at RH of 35\%. The different superscript letters show a significant difference between the mean values $(p<0.05)$.

\section{Discussion}

Knowledge of the flight and dispersal capacities of cerambycid beetles is essential for establishing quarantine zones, setting survey boundaries, studying key factors affecting the species' survival, and modeling the potential spread of the exotic or alien pest. The flight potential of insect species might provide essential data for management decisions [23,24]. Nevertheless, the flight capacity, dispersal, and mobility patterns of J. hammerschmidtii populations in date palm groves are unknown. Several factors, including habitat structure, climatic conditions, and other biotic factors, could significantly affect the beetle in-groves and long-distance dispersal. In addition, the sizes of individuals in populations might affect the speed of flight and distance flown. In this respect, Hanks et al. [25] reported that adult individuals of the cerambycid Phoracantha semipunctata Fabricius with larger sizes dispersed for longer distances than smaller ones. In the present study, we attempted to reveal some flight characteristics of this important date palm insect pest in the laboratory using a computerized flight mill under controlled conditions.

Our results revealed that the flight threshold for a J. hammerschmidtii adult was $20^{\circ} \mathrm{C}$, and ambient temperature in the flight system should be well above this threshold to initiate flight activity in this species. Above the flight temperature threshold, the beetle flight activity increased with increasing temperature until it reached the optimum temperature of $35^{\circ} \mathrm{C}$, where the maximum flight occurred. The relationship between temperature and flight parameters, notably flight speed $(\mathrm{m} / \mathrm{min})$, cumulative flight time $(\mathrm{min})$, and cumulative flight distance $(\mathrm{km})$ was significant. This reflects the impact of ambient temperature on the flight characteristic of this insect. Being ectothermic animals, insects depend mainly on the temperature of the surrounding environment [26], and increasing temperature to the thermal optima increases the metabolism and eventually the insect activities, including flight. Under semi-field conditions, the optimum temperature for adult emergence of J. hammerschmidtii in Iraq ranged between 33 and $34{ }^{\circ} \mathrm{C}$ [7], which conforms with our study. Hanks et al. [25] reported that the dispersal of $P$. semipunctata declines sharply as the temperature falls below $22{ }^{\circ} \mathrm{C}$, whereas Keena [27] stated that the cerambycid beetle Anoplophora glabripennis Motschulsky could not fly at the temperature of $15{ }^{\circ} \mathrm{C}$, and $95 \%$ of test beetles flew at the temperature of $30^{\circ} \mathrm{C}$. 
Methods other than flight mills used to estimate the flight capabilities of cerambycid beeltes include mark-recapture and radio-tracking (telemetry). For example, Drag and Cizek [24] studied the dispersal ability of the great Capricorn beetle, Cerambyx cerdo L. that damages oak trees using a radio-tracking approach and a mark-recapture method. They reported that the beetle flew $1498 \mathrm{~m}$ and $1080 \mathrm{~m}$ in one day for males and females, respectively. The radio-tracking approach revealed that the beetle has a high dispersal ability, whereas the mark-recapture method suggested a low dispersal tendency and sedentary behavior. In general, the mark-recapture method underestimates insect movement compared with the radio-tracking method [28].

Future studies are required to answer the questions concerning the flight periodicity of the J. hammerschmidtii. Hoddle et al. [29] studied the flight periodicity of the palm weevil, Rhynchophorus palmarum L. on a flight mill. They concluded that flight periodicity data should be taken with caution, as weevils on a flight mill lose tarsal contact with a substrate. This could terminate flight and obtain different information from what has been reported. The time when the flight mill studies commence would determine the initiation of flight activities due to the loss of contact of tethered insects with a substrate [29]. The cerambycid beetle $P$. semipunctata was forced to fly during the day, although it is well known as a nocturnal flyer [25]. They further stated that this forced day flight subjected the beetle to predation by birds. The experimental design, including the weight of the rotating arm, the resistance of friction, and the angle with which the beetle was tethered to the rotating arm, greatly influenced insect flight activity. Using smart traps with pheromones could solve the problem of the longhorn beetle flight periodicity. However, a sex or aggregation pheromone has not yet been discovered for J. hammerschmidtii. Most of the cerambycids in the temperate regions are day flyers (diurnal), whereas those in the tropics are night flyers (nocturnal) [30]. The diurnal beetles are faster in flight than the nocturnal ones, which are more readily attracted to artificial light [31]. Several investigators reported that adults of J. hammerschmidtii are nocturnal, strong flyers, and strongly attracted to artificial light $[4,7,32,33]$.

The results of the present investigation revealed that J. hammerschmidtii can potentially fly an estimated cumulative distance of $\sim 11.5 \mathrm{~km}$. The maximum velocity recorded for this beetle on the flight mill was $107 \mathrm{~m} / \mathrm{min}$. Compared with other cerambycid beetles, the estimated maximum distance flown by Monochamus carolinensis (Olivier) on a flight mill was $10.3 \mathrm{~km}$ [34]. The maximum distance flown by the cerambycid Asian longhorn beetle Anoplophora glabripennis was approximately $14 \mathrm{~km} /$ day [35,36]. They also reported that beetle age and mating status affected the flight propensity of this invasive beetle. Other cerambycids can still fly longer on flight mills; for example, the cerambycid beetle Monochamus galloprovincialis flew an estimated maximum distance of $62.7 \mathrm{~km} \mathrm{[37].} \mathrm{The}$ mean velocity of the Asian longhorn beetle $A$. glabripennis using a harmonic radar was $108 \mathrm{~m} / \mathrm{min}$, and the maximum velocity was $318 \mathrm{~m} / \mathrm{min}$ [38]. However, flight mill data indicated that the beetle had a $66 \mathrm{~m} / \mathrm{min}$ velocity, which was slower than when the beetle was allowed to fly freely. In comparison with the red palm weevil, Rhynchophorus ferrugineus, it has been reported that sex had no significant effect on total distance flown and mean flight velocity by male and female [39,40]. However, Armes and Cooter [41] reported that mating significantly decreased flight duration in the cotton bollworm Helicoverpa armigera (Hübner). Mating status was reported to have no effect on flight activity of the tarnished plant bug Lygus lineolaris (Palisot de Beauvois); however, gravid females flew more than ungarvid ones [42]. From the aforementioned discussion, it seems that the influence of sex, age, and mating status on the flight parameters of the J. hammerschmidti need to be further investigated in future studies. The data on the flight propensity of the J. hammerschmidtii presented in this investigation reflects the capacity of this beetle to disperse in date palm plantations in the absence of human-assisted movement of infested date palms intended for cultivation or use in landscape designs. This data could also be used in setting up date palm in-grove management strategies and the demarcation of quarantine boundaries. 


\section{Conclusions}

Flight mill data showed that the J. hammerschmidtii is a strong flyer and can potentially fly for long distances. Air temperature greatly influences the beetle flight parameters, such as fight velocity, flight time, and distance flown. It is more challenging to determine flight periodicity on a flight mill, due to the loss of tarsal contact to the substrate of the tethered insect, which usually initiates flight. The preliminary results presented in this study may pave the way for more future investigations on the effect of sex, age, mating status, and season on the flight characteristics of J. hammerschmidti. Such information on the flight behavior of this beetle is needed for designing management strategies for this pest.

Author Contributions: Conceptualization, M.M. and H.E.-S.; methodology, M.M. and H.E.-S.; software, M.M.; validation, M.M. and H.E.-S.; formal analysis, M.M.; investigation, M.M. and H.E.-S.; resources, N.A.; data curation, M.M. and H.E.-S.; writing-original draft preparation, M.M. and H.E.-S.; writing-review and editing, M.M. and H.E.-S.; visualization, M.M.; project administration, M.M. and H.E.-S.; funding acquisition, N.A. All authors have read and agreed to the published version of the manuscript.

Funding: This research was funded by the Date Palm Research Center of Excellence, King Faisal University, KSA, through funding the research project No DPRC-06-(2018).

Institutional Review Board Statement: Not applicable.

Informed Consent Statement: Not applicable.

Data Availability Statement: Not applicable.

Acknowledgments: The logistic and financial support provided, for this study, by the Date Palm Research Center of Excellence, King Faisal University, is appreciated and sincerely acknowledged.

Conflicts of Interest: The authors declare no conflict of interest.

\section{References}

1. Al-Yahyai, R.; Khan, M.M. Date palm status and perspective in Oman. In Date Palm Genetic Resources and Utilization; Springer: Berlin/Heidelberg, Germany, 2015; pp. 207-240.

2. $\quad$ El-Shafie, H.A.F.; Abdel-Banat, B.M.A.; Al-Hajhoj, M.R. Arthropod pests of date palm and their management. CAB Rev. Perspect. Agric. Vet. Sci. Nutr. Nat. Resour. 2017, 12,1-18. [CrossRef]

3. Blumberg, D. Date palm arthropod pests and their management in Israel. Phytoparasitica 2008, 36, 411-448. [CrossRef]

4. El-Shafie, H.A.F. Biology, ecology and management of the longhorn date palm stem borer Jebusaea hammerschmidti (Coleoptera: Cerambycidae). Outlooks Pest Manag. 2015, 26, 20-23. [CrossRef]

5. Ali, A.S.A.; Hama, N.N. Integrated management for major date palm pests in Iraq. Emirates J. Food Agric. 2016, 28, 24-33. [CrossRef]

6. Abd AL-Saheb, A.-J.; AL-kariti, O. Study the Situation of palm borers in some orchards of Karbala by using different kind of traps. J. Kerbala Agric. Sci. 2019, 2, 28-38.

7. Al-Saeedi, H.M.L. Ecology, Biology, and Evaluation of Some Pest Management Methods of Longhorn Date Palm Stem Borer, Jebusaea hammerschmidtii (Coleoptera: Cerambycidae); University of Baghdad: Baghdad, Iraq, 2019.

8. El-Shafie, H.A.F. The longhorn beetle Jebusaea hammerschmidtii Reiche (Coleoptera: Cerambycidae): An old serious pest undermining date palm plantations. CAB Rev. 2021, 16, 033. [CrossRef]

9. Dias, G.B.; Aldossary, A.M.; El-Shafie, H.A.F.; Alhoshani, F.M.; Al-Fageeh, M.B.; Bergman, C.M.; Manee, M.M. Complete mitochondrial genome of the longhorn date palm stem borer Jebusaea hammerschmidtii (Reiche, 1878). Mitochondrial DNA Part B 2021, 6, 3214-3216. [CrossRef]

10. Kinawy, M. Major Arthropod Pests of Date Palm in Arab Countries. In Proceedings of the First Regional Conference on Date Palm Pest Management, Amman, Jordan, 13-14 November 2012; pp. 44-63.

11. Dhiab, I.M.; Swayir, I.A.; Abdul-Hadi, I. Investigation on palm-stem borer Pseudophilus testasceus Gah Coleoptera Cerambycidae). Yearb. Plant Prot. 1979, 2, o3-o112.

12. Al-Azawi, A.F. A survey of insect pests of date palms in Qatar. Date Palm J. 1986, 4, 247-266.

13. Howard, F.W.; Moore, D.; Giblin-Davis, R.M.; Abad, R. Insects on Palms.(Ecological Studies 142.). Biol. Plant. 2002, $45,196$.

14. El-Shafie, H.A.F.; Mohammed, M.E.A. Description and quantification of damage incurred by the longhorn date palm stem borer Jebusaea hammerschmidtii Reiche, 1877 (Coleoptera: Cerambycidae) on date palm (Phoenix dactylifera Linnaeus, 1753). Int. J. Entomol. Res. 2016, 4, 55-65.

15. Gharib, A. Pseudophilus testaceus Gah = Jebusaea hammerschmidti Reiche (Coleoptera, Cerambycidae). Appl. Entomol. Phytopathol. $1967,25,21-26$. 
16. Carpenter, J.B.; Elmer, H.S. Pests and Diseases of the Date Palm; US Department of Agriculture, Science and Education Administration: Honolulu, HI, USA, 1978; Volume XXX, ISBN 3663537137.

17. Kariyanna, B.; Mohan, M.; Das, U.; Biradar, R.; Anusha Hugar, A. Important longhorn beetles (Coleoptera: Cerambycidae) of horticulture crops. J. Entomol. Zool. Stud. 2017, 5, 1450-1455.

18. El-Shafie, H.A.; Mohammed, M.E.; Sallam, A.K.A. Quarantine protocol against coleopteran borers in date palm offshoots using eco2fume gas. Outlooks Pest Manag. 2020, 31, 190-192. [CrossRef]

19. Hoddle, M.S.; Hoddle, C.D.; Milosavljević, I. Quantification of the life time flight capabilities of the south american palm weevil, Rhynchophorus palmarum (L.) (coleoptera: Curculionidae). Insects 2021, 12, 126. [CrossRef]

20. Ribak, G.; Barkan, S.; Soroker, V. The aerodynamics of flight in an insect flight-mill. PLoS ONE 2017, 12, e0186441. [CrossRef]

21. Mohammed, M.; El-Shafie, H.; Alqahtani, N. Design and validation of computerized flight-testing systems with controlled atmosphere for studying flight behavior of red palm weevil, Rhynchophorus ferrugineus (Olivier). Sensors 2021, 21, 2112. [CrossRef]

22. Mohammed, M.E.A.; El-Shafie, H.A.F.; Al-Hajhoj, M.B.R. Design of an automated solar-powered light trap for monitoring and mass trapping of major date palm pests. Ecol. Environ. Conserv. 2018, 24, 177-185.

23. Haack, R.A.; Hérard, F.; Sun, J.; Turgeon, J.J. Managing invasive populations of asian longhorned beetle and citrus longhorned beetle: A worldwide perspective. Annu. Rev. Entomol. 2010, 55, 521-546. [CrossRef]

24. Drag, L.; Cizek, L. Radio-Tracking Suggests High Dispersal Ability of the Great Capricorn Beetle (Cerambyx cerdo). J. Insect Behav. 2018, 31, 138-143. [CrossRef]

25. Hanks, L.M.; Millar, J.G.; Paine, T.D. Dispersal of the Eucalyptus Longhorned Borer (Coleoptera: Cerambycidae) in Urban Landscapes. Environ. Entomol. 1998, 27, 1418-1424. [CrossRef]

26. Jaworski, T.; Hilszczański, J. The effect of temperature and humidity changes on insects development their impact on forest ecosystems in the expected climate change. For. Res. Pap. 2014, 74, 345-355. [CrossRef]

27. Keena, M.A. Factors that influence flight propensity in Anoplophora glabripennis (Coleoptera: Cerambycidae). Environ. Entomol. 2018, 47, 1233-1241. [CrossRef] [PubMed]

28. Daniel Kissling, W.; Pattemore, D.E.; Hagen, M. Challenges and prospects in the telemetry of insects. Biol. Rev. 2014, 89, 511-530 [CrossRef]

29. Hoddle, M.S.; Hoddle, C.D.; Milosavljević, I. How Far Can Rhynchophorus palmarum (Coleoptera: Curculionidae) Fly? J. Econ. Entomol. 2020, 113, 1786-1795. [CrossRef]

30. Duffy, E.A.J. A Monograph of the Immature Stages of Australasian Timber Beetles (Cerambycidae); British Museum (Natural History): London, UK, 1963

31. Linsley, E.G. Ecology of Cerambycidae. Annu. Rev. Entomol. 1959, 4, 99-138. [CrossRef]

32. Hussain, A.A. Notes on borers of date palms in Iraq. Bull. Entomol. Res. 1963, 54, 345-348. [CrossRef]

33. Al-Deeb, M.A.; Khalaf, M.Z. Longhorn Stem Borer and Frond Borer of Date Palm. In Sustainable Pest Management in Date Palm: Current Status and Emerging Challenges; Springer: Berlin/Heidelberg, Germany, 2015; pp. 63-72.

34. Akbulut, S.; Linit, M.J. Flight performance of Monochamus carolinensis (Coleoptera: Cerambycidae) with respect to nematode phoresis and beetle characteristics. Environ. Entomol. 1999, 28, 1014-1020. [CrossRef]

35. Lopez, V.M.; Hoddle, M.S.; Francese, J.A.; Lance, D.R.; Ray, A.M. Assessing Flight Potential of the Invasive Asian Longhorned Beetle (Coleoptera: Cerambycidae) with Computerized Flight Mills. J. Econ. Entomol. 2017, 110, 1070-1077. [CrossRef]

36. Javal, M.; Roux, G.; Roques, A.; Sauvard, D. Asian Long-horned Beetle dispersal potential estimated in computer-linked flight mills. J. Appl. Entomol. 2018, 142, 282-286. [CrossRef]

37. David, G.; Giffard, B.; Piou, D.; Jactel, H. Dispersal capacity of Monochamus galloprovincialis, the European vector of the pine wood nematode, on flight mills. J. Appl. Entomol. 2014, 138, 566-576. [CrossRef]

38. Williams, D.W.; Li, G.; Gao, R. Tracking movements of individual Anoplophora glabripennis (Coleoptera: Cerambycidae) adults: Application of harmonic radar. Environ. Entomol. 2004, 33, 644-649. [CrossRef]

39. Ávalos, J.A.; Martí-Campoy, A.; Soto, A. Study of the flying ability of Rhynchophorus ferrugineus (Coleoptera: Dryophthoridae) adults using a computer-monitored flight mill. Bull. Entomol. Res. 2014, 104, 462-470. [CrossRef]

40. Hoddle, M.S.; Hoddle, C.D.; Faleiro, J.R.; El-Shafie, H.A.F.; Jeske, D.R.; Sallam, A.A. How Far Can the Red Palm Weevil (Coleoptera: Curculionidae) Fly? Computerized Flight Mill Studies with Field-Captured Weevils. J. Econ. Entomol. 2015, 108, 2599-2609. [CrossRef] [PubMed]

41. Armes, N.J.; Cooter, R.J. Effects of age and mated status on flight potential of Helicoverpa armigera (Lepidoptera: Noctuidae). Physiol. Entomol. 1991, 16, 131-144. [CrossRef]

42. Stewart, S.D.; Gaylor, M.J. Effects of age, sex, and reproductive status on flight by the tarnished plant bug (Heteroptera: Miridae). Environ. Entomol. 1994, 23, 80-84. [CrossRef] 